M. ALUSHLLARI ${ }^{1 *}$, S. MICO ${ }^{2}$

${ }^{1}$ University of Tirana, Institute of Applied Nuclear Physics, Tirana, Albania, ${ }^{2}$ University of Vlore, Department of Physics, Vlore, Albania
Scientific paper

ISSN 0351-9465, E-ISSN 2466-2585

UDC:669.24/.29:628.113(285.2)

doi:10.5937/ZasMat1504492A

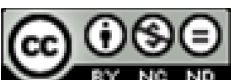

Zastita Materijala 56 (4)

492 - 495 (2015)

\title{
Analyses of heavy metals in the superfical water of lakes
}

\begin{abstract}
Heavy metal pollution presents a serious problem for human health and ecosystems. During this survey we were collected a total number of 16 surface water samples. The analyses of four heavy metals, Cadmium, Chromium, Copper and Lead, were performed at the Institute of Applied Nuclear Physics, University of Tirana, using Graphite Furnace Atomic Absorption Spectrometry. The current study reports the presence of heavy metals $\mathrm{Cd}, \mathrm{Cr}, \mathrm{Cu}$ and $\mathrm{Pb}$ in selected samples. Their concentrations are resulted to be quite low. Average concentrations of metals in the surface water samples were: $\mathrm{Pb}-2.14 \mu \mathrm{g} / \mathrm{L}$; Cd-0.04 $\mu \mathrm{g} / \mathrm{L}$; Cr-9.44 $\mu \mathrm{g} / \mathrm{L}$; Cu-3.28 $\mu \mathrm{g} / \mathrm{L}$. The concentration of heavy metals in surface water samples is compared with maximum contaminant levels recommended by World Health Organization and Environmental Protection Agency. From the results obtained, none of the analyzed samples contained heavy metals concentrations above the $M C L$ determined from EPA. One of all surface water samples contained the chromium element $6.8 \%$ higher than the MCL determined from WHO.
\end{abstract}

Keywords: heavy metals, surface water, atomic absorption spectrometry.

\section{INTRODUCTION}

Both anthropogenic and natural processes are the sources for degradation of quality in surface water and groundwater [1]. Water is one of the most important natural resources for life development [2]. Mostly, surface water has poor quality in our environments. Among others, heavy metals are present in the surface water. The presence of heavy metals in surface water causes serious health effects and symptoms such as: kidneys and heart diseases, damages of the nervous system, other epidermises and cancer [3]. Heavy metal pollution represents a serious problem not only for human health, but to aquatic ecosystems and life as well [4]. Lead and its compounds are toxic; they can enter the human body through food, water and air [5]. Our purpose is to identify and compare the metals $\mathrm{Cd}, \mathrm{Cr}, \mathrm{Cu}$ and $\mathrm{Pb}$ in surface water, depending on weather conditions. The object of the study is water of Artificial and Farka lakes, in Tirana, Albania, during two seasons. The current study reports the analysis of metals $\mathrm{Cd}, \mathrm{Cu}, \mathrm{Pb}$ and $\mathrm{Cr}$ of the Artificial and Farka lakes during two

${ }^{*}$ Corresponding author: M. Alushllari

E-mail: m.alushllari@gmail.com

Paper received: 26. 06. 2015.

Paper accepted: 12. 08. 2015.

Paper is available on the website:

www.idk.org.rs/casopis seasons. The concentration of heavy metals in surface water samples is compared with MCL of these metals recommended by EPA [6] and WHO [7]. One of the techniques used to determine the elements in the environment and especially on water is classified AAS methods.

\section{MATERIAL AND METHODS}

Representative samples of surface water are collected in the Artificial and Farka lakes, located in the south western city of Tirana. There are 8 sampling points selected (5-Artificial Lake; 3-Farka Lake) and collected a total of 16 surface water samples. Samples were collected in two seasons, spring and winter. Water samples are analyzed using Graphite Furnace Atomic Absorption Spectrometer, Aanalyst 800 Perkin-Elmer, autosampler AS-800. Hollow cathode lamps were used as radiation source. Acids and reagents used for the digestion of samples, preparation of standard solutions have high grade purity. All water samples are filtered and $\mathrm{pH}$ was measured in 6.7-7.1 ranges. The samples were acidified with nitric acid until pH 2, after was added MIBK. $200 \mathrm{ml}$ of water sample transferred in a glass of $250 \mathrm{ml}$, added $4 \mathrm{ml}$ HNO3CC and digested in a hot plate for about 2 hours, until 1-3 $\mathrm{ml}$. Samples were being cooled to 
room temperature, add $1 \mathrm{ml} \mathrm{HClcc}$, transferred in a balloon of $25 \mathrm{ml}$ and filled with bidistil water. Three applications were carried out for the measurement of blank, calibration standards and samples. A calibration curve defined using this equation is forced to go through zero absorbance and zero concentration. Instrumental parameters are based on Analytical Methods of AAS [8]. The correlation coefficient of the calibration curves for the analyzed elements $\mathrm{Cd}, \mathrm{Cu}, \mathrm{Cr}$ and $\mathrm{Pb}$ were respectively: $0.99854 ; 0.99644 ; 0.99512 ; 0.99589$. Reference standard solution "AA Test Mix by Perkin Elmer" was used for the analytical quality control of the analysis. For control of interference used modifier matrix according standard conditions by AAS_GF with Zeeman-Effect Background correction.

\section{RESULTS AND DISCUSSION}

In Table 1 are presented the concentrations of $\mathrm{Cd}, \mathrm{Cr}, \mathrm{Cu}$ and $\mathrm{Pb}$ in the surface water samples. The level of heavy metals in water is compared with MCL specified by WHO and EPA for each element.

Table 1 - Concentration of heavy metals in the representative surface water samples.

\begin{tabular}{|c|c|c|c|c|c|c|}
\hline Number & Sampling & Code & $\mathrm{Pb}(\mu \mathrm{g} / \mathrm{L})$ & $\mathrm{Cd}(\mu \mathrm{g} / \mathrm{L})$ & $\mathrm{Cr}(\mu \mathrm{g} / \mathrm{L})$ & $\mathrm{Cu}(\mu \mathrm{g} / \mathrm{L})$ \\
\hline \multicolumn{7}{|c|}{ Sampling_I } \\
\hline 1 & $S-1 \_A L$ & M_1 & $4.4 \pm 0.01$ & $0.056 \pm 0.12$ & $53.4 \pm 3.2$ & $8.9 \pm 0.8$ \\
\hline 2 & S_2_AL & M_2 & $2.7 \pm 0.3$ & $0.017 \pm 0.02$ & $36.7 \pm 1.5$ & $2.8 \pm 0.02$ \\
\hline 3 & S_3_AL & M_3 & $4.9 \pm 0.02$ & $0.1 \pm 0.42$ & $42.4 \pm 0.98$ & $3.6 \pm 0.03$ \\
\hline 4 & S_4_AL & M_4 & $3.9 \pm 1.4$ & $0.1 \pm 0.081$ & $9.8 \pm 1.3$ & $1.9 \pm 0.71$ \\
\hline 5 & S_5_AL & M_5 & $2.1 \pm 1.1$ & $0.08 \pm 0.52$ & $1.1 \pm 0.04$ & $4.4 \pm 0.02$ \\
\hline 6 & S_1_FL & M_6 & $2.9 \pm 0.4$ & $0.2 \pm 0.04$ & $0.9 \pm 0.03$ & $2.8 \pm 0.07$ \\
\hline 7 & S_2_FL & M_7 & $4.1 \pm 3.2$ & $0.02 \pm 0.06$ & $1.9 \pm 0.01$ & $1.2 \pm 2.8$ \\
\hline 8 & S_3_FL & M_8 & $3.9 \pm 0.1$ & 0 & $5.2 \pm 0.01$ & $2.7 \pm 0.04$ \\
\hline 9 & Rainwater & M_9 & $3.1 \pm 0.31$ & $0.02 \pm 0.01$ & $1.9 \pm 0.01$ & $4.1 \pm 2.1$ \\
\hline \multicolumn{7}{|c|}{ Sampling_II } \\
\hline 10 & S-1_AL & M_10 & $1.9 \pm 0.3$ & 0 & $1.8 \pm 1.6$ & $2.9 \pm 0.04$ \\
\hline 11 & S_2_AL & M_11 & $0.2 \pm 0.21$ & 0 & $1.5 \pm 0.03$ & $7.1 \pm 0.01$ \\
\hline 12 & S_3_AL & M_12 & 0 & 0 & $0.2 \pm 0.01$ & $4.8 \pm 0.03$ \\
\hline 13 & S_4_AL & M_13 & 0 & 0 & 0 & $1.3 \pm 0.91$ \\
\hline 14 & S_5_AL & M_14 & $0.2 \pm 0.01$ & $0.01 \pm 0.01$ & $0.8 \pm 0.01$ & $3.2 \pm 0.67$ \\
\hline 15 & S_1_FL & M_15 & $1.7 \pm 0.031$ & 0 & $0.6 \pm 0.04$ & $1.4 \pm 0.54$ \\
\hline 16 & S_2_FL & M_16 & 0 & $0.02 \pm 0.01$ & $0.9 \pm 0.05$ & $1.5 \pm 0.81$ \\
\hline 17 & S_3_FL & M_17 & $0.4 \pm 1.3$ & $0.01 \pm 0.05$ & $1.3 \pm 0.02$ & $1.1 \pm 0.12$ \\
\hline 18 & WHO & & 10 & 50 & 50 & 2000 \\
\hline 19 & EPA & & 15 & 5 & 100 & 1300 \\
\hline
\end{tabular}

Note: AL-Artificial Lake \& FL-Farka Lake

From the results obtained, the metals were found to be present in $85.3 \%$ of the all samples analyzed, where $82.36 \%$ of samples containing $\mathrm{Pb}$; $64.71 \% \mathrm{Cd} ; 94.12 \% \mathrm{Cr}$ and $100 \% \mathrm{Cu}$. Concentration levels of elements during tow sampling periods varied in the range: $\mathrm{Cd}(0-0.04) \mu \mathrm{g} / \mathrm{L} ; \mathrm{Cr}(0-$
53.4) $\mu \mathrm{g} / \mathrm{L} ; \mathrm{Cu}(1.1-8.9) \mu \mathrm{g} / \mathrm{L} ;$ and $\mathrm{Pb}(0-4.9) \mu \mathrm{g} / \mathrm{L}$. Metal levels in the sample M_9 (rain water) was the result of the presence of metals in the atmosphere. Compared to EPA level concentrations of above mentioned elements, our samples showed very low values. Comparison of the M_1 sample for chro- 
mium element with WHO level resulted $6.8 \%$ higher.

In Figure 1 are presented concentrations of $\mathrm{Cd}$, $\mathrm{Cr}, \mathrm{Cu}$ and $\mathrm{Pb}$ that are found during the two sampling periods. In Figure 2 is presented box plot for distribution of metals $\mathrm{Cd}, \mathrm{Cr}, \mathrm{Cu}$ and $\mathrm{Pb}$ in water samples. In Figure 3 is presented scatter plot for correlation of metals between sampling I and sampling II. This correlation was weak. In Figure 4 is presented the tree diagram of metal contents of $\mathrm{Cd}, \mathrm{Cr}, \mathrm{Cu}$ and $\mathrm{Pb}$ during sampling-I and samplingII

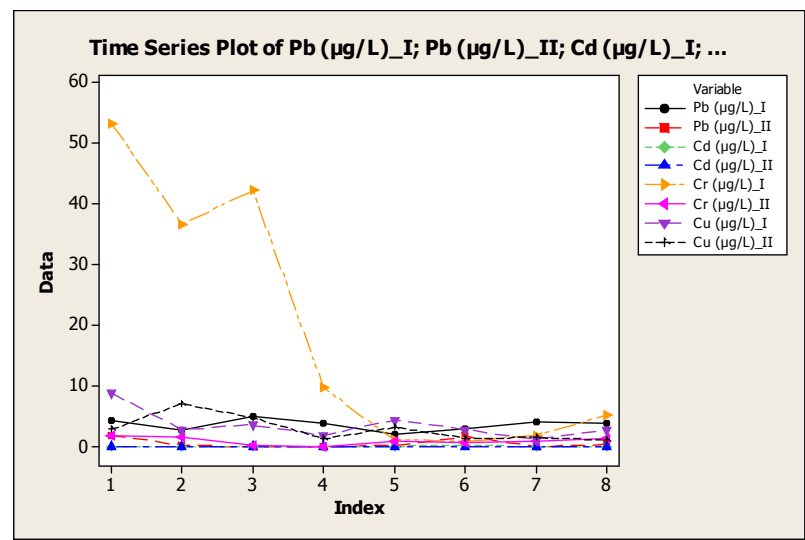

Figure 1 - Metals in water during two sampling

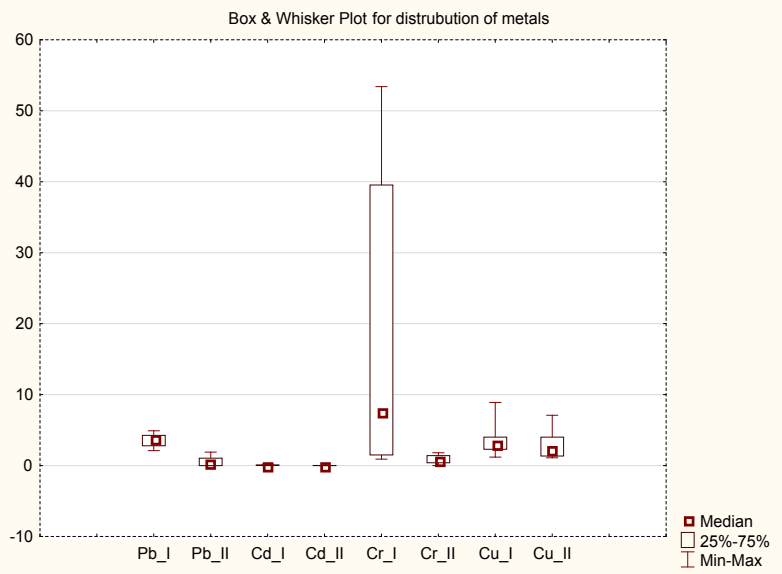

Figure 2 - Distribution of metals in all samples

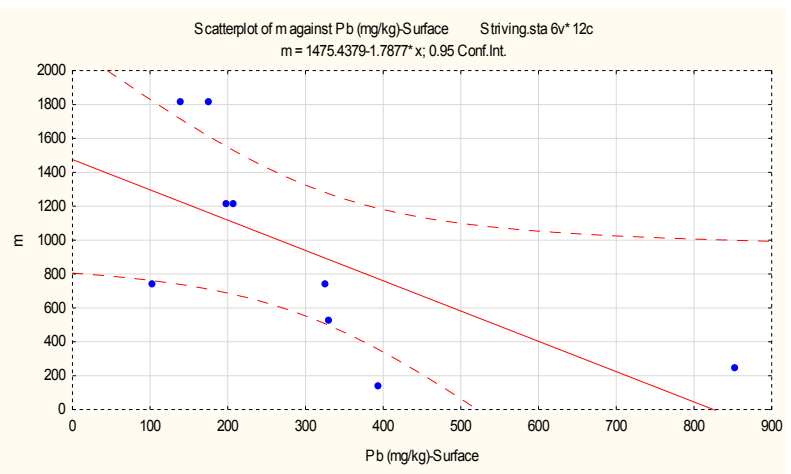

Figure 3 - Correlation of metals between sampling

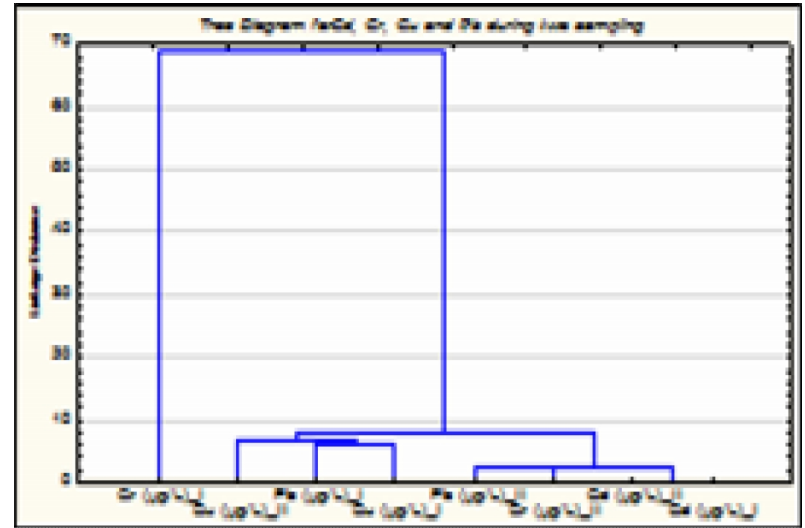

Figure 4 - Tree diagram of metal content in water

\section{CONCLUSION}

The metal levels during the first sampling period were higher than the metal levels during the second sampling period. Also, metal levels in representative Artificial Lake samples were higher than the metal levels in Farka Lake water samples. Firstly, affecting precipitation, atmospheric particles pass from the atmosphere on land and water and secondly, water discharges to the lake area along with solid materials. Over population of Artificial Lake area, discharges of zoo garden and community wastes may cause serious problems of metal pollution of surface water.

By comparing the metal concentrations in water samples with MCL recommended by WHO only one of the water sample contained chromium above this concentration.

Heavy metals $\mathrm{Cd}, \mathrm{Cr}, \mathrm{Cu}$ and $\mathrm{Pb}$ were present in the most of analysed samples, although it should be noted that their concentrations are quite low.

\section{REFERENCES}

[1] S.R.Carpenter, N.F.Caraco, D.L.Correll, R.W. HoWarth, A.N.Sharpely, V.H.Smith (1998) Nonpoint Pollution of surface Waters with phosphorus and nitrogen, Ecological Applications., 8, 559-568.

[2] G.W.Vanloon, S.J. Duffy (2005) The Hydrosphere. Environmental Chemistry: A Global Perspective., 2nd Edn. New York: Oxford University, Press, p.197-211.

[3] M.Alushllari, N.Civici, I.Malollari (2012) Study and Verification of the Content of Arsenic (As), Cobalt (Co) and Copper $(\mathrm{Cu})$ in Surface Water in the Region of Tirana City, Albania, JIEAS, 7(2), 205209.

[4] P.Censi, S.E.Spoto, F.Saiano, M.Sprovieri, S.Mazzola, G.Nardone, S.I.Di Geronimo, R.Punturo, D.Ottonello (2006) Heavy metals in coastal Water system, Chemosphere, 64,1167-1176. 
[5] M.Alushllari, N.Civici (2014) Analyses of Lead in Water Depend the Weather, near the Ex-Factory Production of Batteries Region, Berat, Albania.,Applied Science Reports, p.122-125.

[6] Anonymous, EPA drinking Water standard. (1993) http:/Water.epa.gov/drink/contaminants/index. cfm\#Inorganic.
[7] Anonymous (1993) WHO, s drinking Water standard 1993.

www.lenntech.com/applications/drinking/standards/ Who-s-drinking-Water- standards.htm

[8] Analytical methods for Atomic Absorption Spectroscopy and Recommended conditions for THGA furnaces and Recommended conditions for THGA furnaces (Perkin - Elmer).

\section{IZVOD}

\section{ANALIZA TESKIH METALA U POVRSINSKIM VODAMA JEZERA}

Teška zagađenja metala predstavljaju ozbiljan problem za ljudsko zdravlje i ekosisteme. Tokom ovog istraživanja sakupljeno je 16 uzoraka površinskih voda jezera. Analize četiri teških metala, kadmijum, hrom, bakar i olovo, izvedena su u Institutu za primenjenu nuklearnu fiziku, Univerziteta u Tirani, koristeći grafitnu peć za atomsku spektrometrijom.

Rezultati ispitivanja su pokazali prisustvo teških metala $\mathrm{Cd}, \mathrm{Cr}$, Cu i Pb u odabranim uzorcima. Njihove koncentracije su bile prilično niske. Prosečne koncentracije metala u uzorcima površinske vode bili su: $\mathrm{Pb}-2.14 \mathrm{mg} / \mathrm{L}$; Cd- 0.04 ug / L ; Cr- 9.44 ug / L ; Cu- 3.28 ug / L . Koncentracija teških metala u uzorcima površinskih voda je u poređenju sa maksimalnim nivoima zagađivača voda preporučenih od strane Svetske zdravstvene organizacije i Agencija za zaštitu životne sredine. Od dobijenih rezultata, nijedan od analiziranih uzoraka ne sadrži koncentracije teških metala iznad MCL određene iz EPA. Jedino je jedan od svih uzoraka površinskih voda sadržala hroma $6,8 \%$ sto je vise $u$ odnosu na MCL određen od SZO.

Ključne reci: teški metali, površinske vode, atomska apsorpciona spektrometrija.

Naučni rad

Rad primljen: 26.06.2015.

Rad prihvaćen: 12.08.2015.

Rad je dostupan na sajtu: www.idk.org.rs/casopis 